\title{
Klugee: Web-Based Application for Teaching Mathematics in English to Indonesian Elementary School Students
}

\author{
Bebasari Amiroh \\ Prodi Sastra Inggris, Universitas Ma Chung, Villa Puncak Tidar N1 Malang, Indonesia \\ Correspondence: Bebasari Amiroh (211710003@student.machung.ac.id) \\ Received: 260721 - Revised: 290721 - Accepted: 080821 - Published: 271021
}

\begin{abstract}
Abstrak. Despite the advancement of digital technology, there is no application specializing in teaching mathematics in English for Indonesian elementary school learners. During the pandemic, teachers need online teaching media to assist them when teaching mathematics. This article covers the project of teaching media creation for teaching Common Core mathematics to Indonesian elementary school students. The objectives of this project are creating web-based applications focusing to assist teachers to teach Mathematics in English for Indonesian Elementary students; and providing tools for the teachers in terms of material management such as curriculum and exercises; student management; and step-by-step guide during teaching in the classroom setting. Content and Language Integrated Learning (CLIL) is the teaching method supported by the teaching media. The results of the project are two web-based applications. The first application is the Learning Application which contains the mathematics teaching materials and student management. The second application is the Teaching Guide application, which contains the step-by-step-guide for teachers in CLIL classroom setting. The informal trials with 13 elementary students and 4 mathematics teachers as the participants showed positive results.
\end{abstract}

Kata kunci: Teaching media, CLIL, Teaching mathematics in foreign language, Web-based application

Citation Format: Amiroh, B (2021). Klugee: Web-Based Application for Teaching Mathematics in English to Indonesian Elementary School Students. Prosiding Seminar Nasional Abdimas Ma Chung (SENAM), 2020, 141-155 


\section{INTRODUCTION}

Despite the advancement of digital technology, there is no application specializing in teaching Mathematics in English for elementary school learners. Private elementary schools in Indonesia are starting to incorporate school subjects such as mathematics with English as the medium of instruction in their curriculum. Examples of schools applying school subjects in English are SD My Little Island Malang, Brawijaya Smart School Malang, and Syafan Islamic School Tangerang. However, there is a lack of digital material which is suitable for Indonesian teachers to teach Indonesian elementary students with beginner level of English. Exacerbated by the Covid-19 pandemic which resulted in a full online study method for elementary students, online teaching media to assist teachers is needed.

The use of technology is highly important in this modern era (Karadeniz, 2018). There are free, online materials that can be used by teachers to teach mathematics in English, such as Khan Academy. However, despite being comprehensive and offering lessons in the forms of video, contents in Khan Academy are not easily understood by Indonesian elementary students with beginner English level. The application offers lessons in English, with native English speakers as the target users. Therefore, it does not offer features which are beneficial to help students with beginner English to understand the materials in English independently. Students with beginner English level who are using the application remotely and independently will have difficulty in understanding the exercises and materials as it uses intermediate and advanced grammar and vocabularies.

Teaching mathematics in English means mastering mathematics vocabularies which include basic mathematical operations taught in elementary schools, such as addition, subtraction, multiplication, and division (National Governors Association Center, 2010). The teachers need to be able to explain the operation concept to the students while also training the students to pronounce the vocabularies accurately.

In order to integrate mathematics and English as a foreign language, a certain teaching method is needed. One of the methods of teaching mathematics in English as a foreign language is Content and Language Integrated Learning (CLIL). CLIL is an immersion based teaching method where the classroom learns a certain subject using foreign language (Marsh, 2002) and has been applied in European countries such as Finland, Germany, Belgium, and Netherlands (Marsh, 2013). In this method, students can learn mathematics in a foreign language, while also still being helped by incorporating L1 in the 
beginning of the teaching process (Marsh, 2002). Many studies confirmed the benefits of CLIL. Nikula (2010) stated that students in CLIL class are directly exposed to the target language while learning a meaningful context, which enables them to practice the target language more than in traditional language class. Wakui (2019) stated that in Japanese elementary schools, 100\% participants agreed that learning school subjects in English language led to improvement of their English skills, especially in writing and reading skills. According to Aotani (2017), CLIL activities have great significance where students work on the integration of subject contents they have already learned and the target language, which makes students get into a mode of being proactive. A study done by Surmont in Belgium (2016) found that the CLIL method in mathematics class scored higher in mathematics tests than the non-CLIL class. Prochazkova (2013) in her study mentioned that learning Mathematics in a different language provides the learners with a different perspective on the content area; different vocabulary creates further associations; different methods necessary for instruction through a foreign language, which can trigger a more active approach and deeper understanding.

The writer also develops a private, non-formal education institution named Klugee, which offers CLIL-based mathematics in English for elementary students. Seeing the need of online teaching media for mathematics in English and the potential benefits of applying CLIL in the teaching method, the writer decided to create web-based applications which will help Indonesian teachers to teach Mathematics in English for Indonesian elementary English learners.

\section{Project Objective}

The objective of this project is to create a web-based application aimed to assist teachers to teach Mathematics in English to Indonesian elementary students. The writer's aim is to provide tools for the teachers which facilitate them in material management such as curriculum and exercises; student management, and step-by-step guide on what to do during teaching in the online classroom setting. By using this application, the teachers will have guidance on what to teach next.

\section{Benefits of the Project}

These applications can be used as a tool for elementary school teachers in Indonesia to teach mathematics in English. For schools that want to upgrade their competence and 
supplement their national curriculum with English-based subjects, they do not have to buy licensed affiliation from expensive institutions abroad. This application can be used by elementary schools in Indonesia to give Content and Language Integrated Learning experience at an affordable price. Teachers do not have to collect materials from multiple resources when it comes to creating syllabus or curriculum for teaching mathematics in English. They can access the curriculum, exercises, quizzes, and tests in the application. They can also manage the students into rosters and record their scores in the app. This can reduce the use of paper, thus making the teaching process more eco-friendly and efficient.

\section{CONSTRUCTION METHOD}

\section{Timeline Planning}

The timeline for the creation process started from December 2019 and finished in December 2020.

\section{Team Member Recruitment}

In order to prevent lack of human resources, early recruitment was conducted in December 2019. The team for this project was composed of 14 students from Universitas Ma Chung and 1 student from Institut Teknologi Bandung. From Universitas Ma Chung, there were 4 students from English Letters study program, 3 students from the Visual Communication Design study program, and 7 students from the Informatics Engineering study program. From Institut Teknologi Bandung, there was 1 student from the Informatics Engineering study program.

\section{Creating Curriculum and Content}

The curriculum created for the application needs to follow young learner's cognitive development. Elementary students are in the concrete operational development phase as mentioned by Piaget (2003), where the students can fluently grasp the concept of counting, volume, shapes, and graphs, and questions related to their real-life activities. Based on this development phase, Common Core Standard was chosen as the base curriculum for the application. Common Core is the learning standard of schools in the United States (National Governors Association Center, 2010). Common Core maths, which is also called Core maths, is one of the most widely used curriculum in English speaking countries. It focuses on student's understanding of numbers, instead of memorizing formulas. The Core maths also contains real word-problems which are related to students' daily lives (National Governors 
Association Center, 2010). Remembering that Klugee aims for elementary English learners, the curriculum created starts from the foundation level, which includes the kindergarten level, starting from counting small numbers units. The foundation unit will consist of the very basics for counting numbers in English, which will ease beginner students' in the process of learning. The unit sequence will have a gradual increase in complexities, but still using simple present tense grammar, and at the same time following the Common Core mathematics standard.

The Core Maths units included in the application's first stage development are: Counting and Cardinality, Operations and Algebraic Thinking, Numbers and Operations in Base Ten, Measurement, Data, and Geometry.

Target vocabularies were also listed in each unit. Target vocabularies span from nouns such as number 1 to 1000, animals, food, shapes, toys, buildings and furniture inside the house. Target verbs included are daily activity verbs such as eat, drink, play, buy, cook, jump, read, and open.

\section{Creating Questions and Exercise}

After deciding the curriculum, questions for exercises were created. The questions in the application follow each exercise's details. The answers are in the form of multiple questions, drag and drops, and fill-in-the-blanks. In order to create the questions, analysis on the Common Core Mathematics worksheets was conducted, followed by creating the structure from the worksheets, and finally generating new questions and answers which contain target vocabularies that are suitable for Indonesian elementary English learners.

\section{Deciding the Theme and Design}

The application uses soft blue as the main color theme, followed by white and yellow. The color of blue symbolizes a sense of trust, studiousness, and reliability. White symbolizes purity and clarity, while yellow symbolizes cheerfulness and happiness (Hauff, 2018).

\section{Designing and Creating Application Mock-up}

In this project, there are two applications being built. The first is the main application, which is Klugee Learning application, consisting of lesson contents, exercise contents, classroom management and question management. The second application is Klugee 
Teaching Guide, containing information of step-by-step teaching guide, covering pre teaching, during teaching, and post teaching.

\section{Compiling Illustration Assets}

After creating the mock-up and application design, the next step was creating the illustration assets for Klugee Learning application. For this project, 3 students from Design and Visual Communication study program in Universitas Ma Chung were recruited. They created icon assets and simple animation which will be used in the Klugee Learning Application. The icon assets are organized based on the figure type such as animals, food, furniture, shapes, nature, and bar graphs illustration.

\section{Software Development Process}

Klugee Learning Application (KLA) was built by the team from Universitas $\mathrm{Ma}$ Chung, while Klugee Teaching Guide (KTG) was built by the student from Institut Teknologi Bandung. The development process for KLA took 5 months, while the development of KTG took 3 months.

\section{Application Trial}

After the development was done, the application trial was held. In this trial session, the flow of Klugee Learning application was tested. The trial for the Learning Application (KLA) was conducted with 13 elementary students and 4 elementary mathematics teachers as the users. For the Teaching Guide application, the trial was conducted with 4 elementary mathematics teachers as users.

\section{RESULTS AND DISCUSSION}

Two applications have been built which can be used to assist teachers in the CLIL classroom. The first application is Klugee Learning Application (KLA) which works as the major teaching medium, and the second is Klugee Teaching Guide (KTG) application which works as a supplementary teaching medium

\section{Klugee Learning application}

This application works as the main teaching media, focusing on the lesson and exercise content, classroom management, and question management. This web- application consists of the homepage, teacher's page (TP), the student's page (SP), and the admin page (AP).

\section{Homepage}


The homepage also contains About and Program pages, which are still in the development phase as they are currently not a priority. The About page contains explanation and definition of the application, while the Program page explains the services available, which are online courses and offline courses.

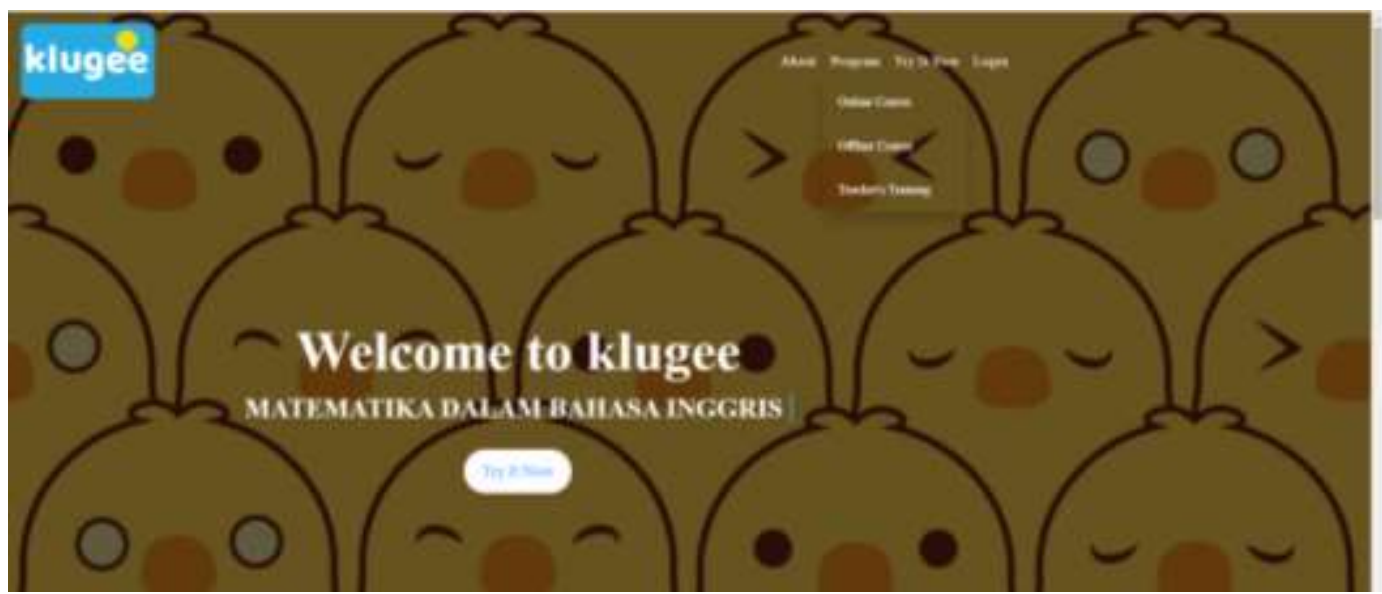

Figure 1. Homepage desktop view

\section{Teachers Page (TP)}

The Teacher's Page (TP) is the page for the teachers as users. TP serves 2 functions which are intended to help teachers in managing classroom, students, and the contents. The first function is the Student Management page, where the teachers can make classroom roster and monitor their students' score. The second function will be the Question Management page, where the teacher can choose sets of questions for different classrooms.

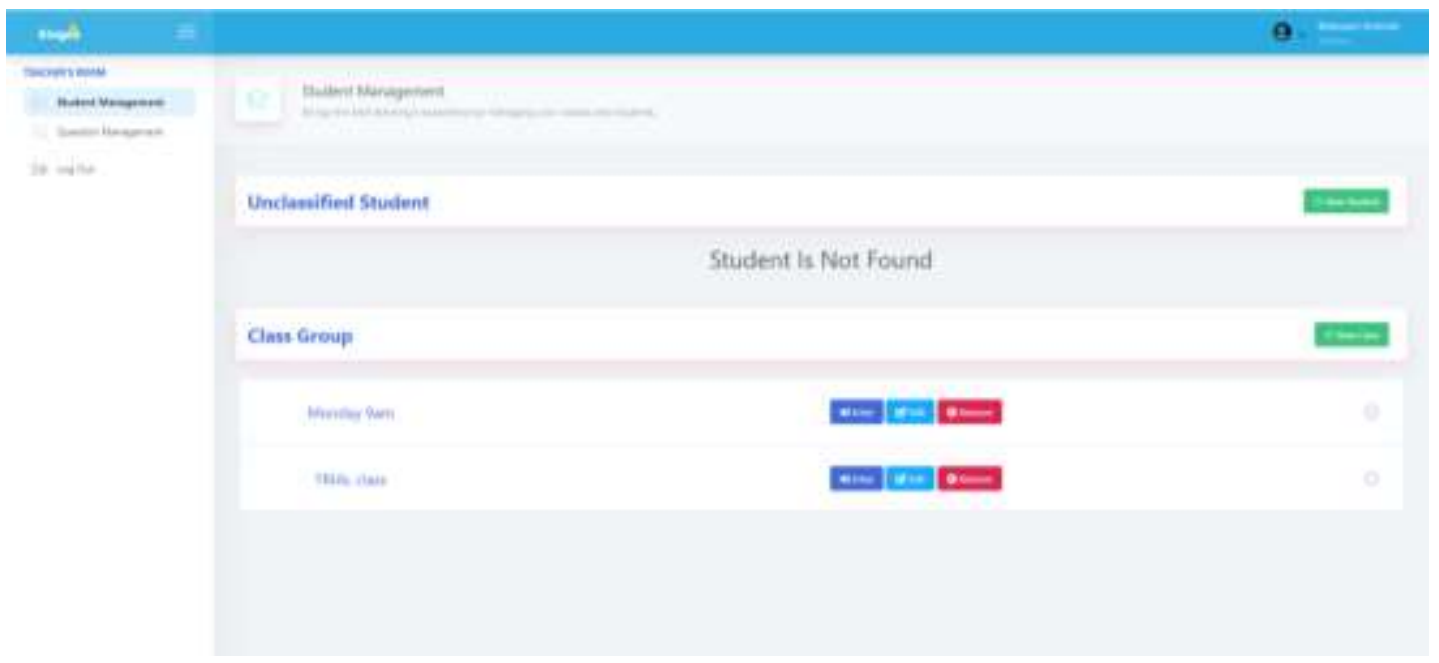

Figure 2. Teachers Page's landing page 


\section{Student Page (SP)}

The Student's Page (SP) is the page where the students can access the lesson and answer the questions in the form of exercise, quiz and unit test, in which the questions will use elements such as drag-and-drops and points earned. Students will have an id and password generated by the teachers, which they can use to access the SP. Starting with the login page, students will arrive at the landing page, where it will lead students to do exercise based on grade, semester, and lessons. Students will need to choose their semester, and it will lead them to unit selection. The unit selection will lead them to lesson selection and the lesson will be composed of video content and exercises students need to do.

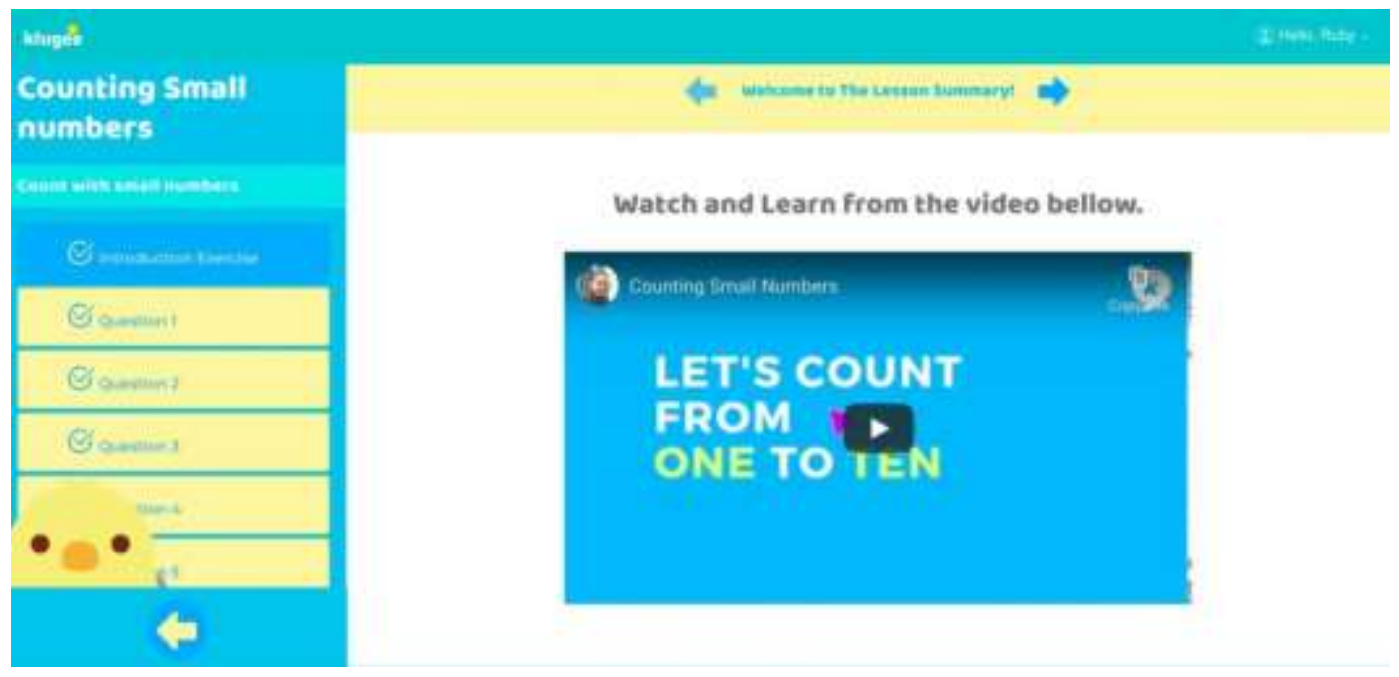

Figure 3. Exercise page on Students Page

\section{Admin Page (AP)}

The admin page (AP) is where the curriculum administrator can add or edit Units, Lessons, Exercise, and Questions. AP can be accessed via the login page where the user input admin username and password. After logging in, it will lead the user to an AP page where the user can access each question in every exercise, such as changing the questions, picture asset, and edit typos in the question. After the user updates the question, the updated version will be kept and applied to TP and SP.

\section{Klugee Teaching Guide application}

Klugee Teaching Guide application works as a guide for teachers in the classroom, informing them what to do during pre-teaching, during teaching, and post teaching. This can ease teacher's effort in teaching, thus helping reduce teachers' workloads. This Teaching Guide application is composed of two main pages, Guiding page and Admin page. 


\section{Guiding Page}

The Guiding page works as the lesson plan guide for teachers as users, where they can follow a step-by-step teaching guide which consists of pre-teaching, during teaching, and postteaching. The Guiding page consists of a Login page, Class Selection page, Material Selection page,Teaching phase page and Lesson Guiding page.

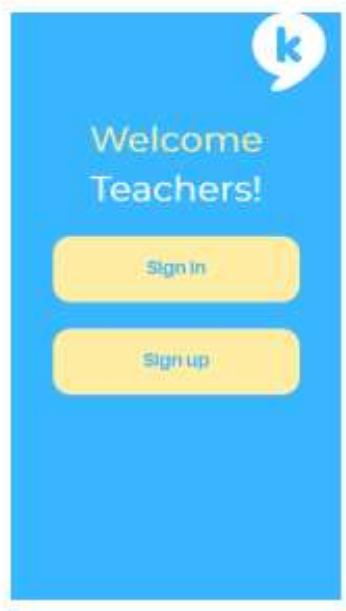

a

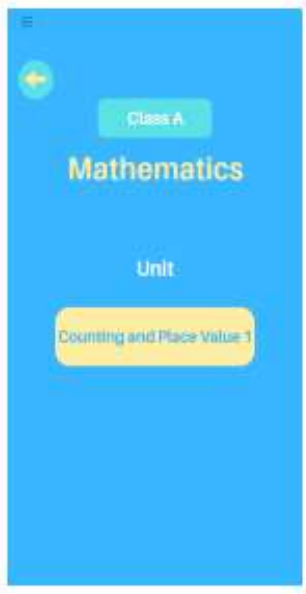

d

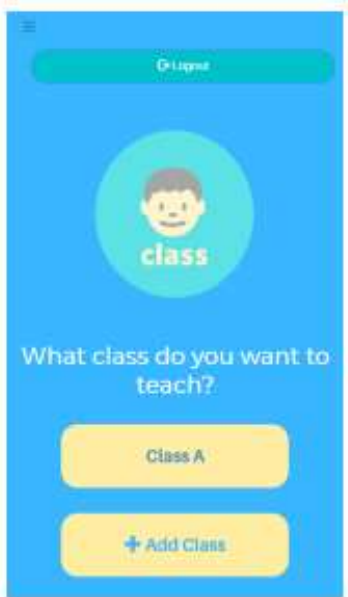

b

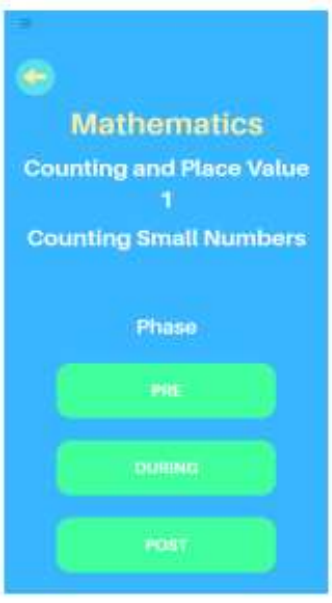

e

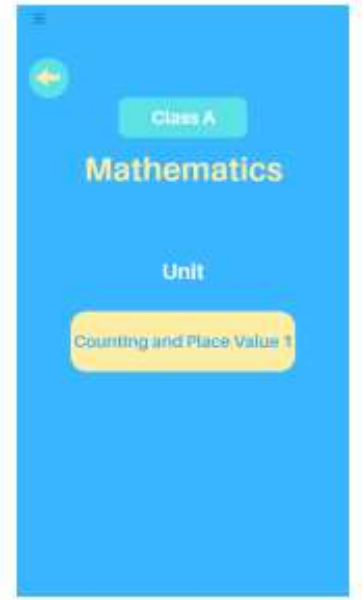

c

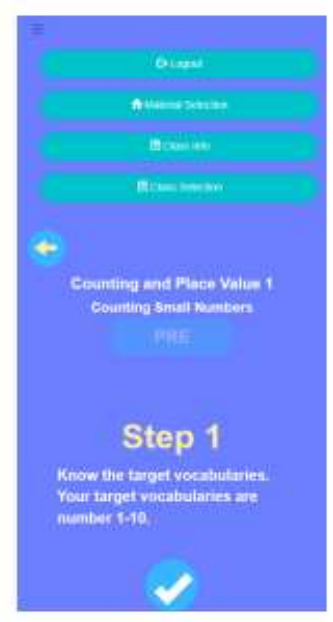

f

Figure 4. Klugee KTG Guiding page, a. Login page, b. Class Selection page, c and d. Material Selection page, e. Teaching page, f. Lesson Guiding page.

\section{KTG Admin Page}

The Admin page in the Teaching Guide application works as materials input and organizer. In this page, users can add new subjects, new units in the existing subjects, new lessons in the existing units, and the step-by-step guide in every phase. The Admin page consists of Topic and Unit page, Add Lesson page, and Step by Step page. 

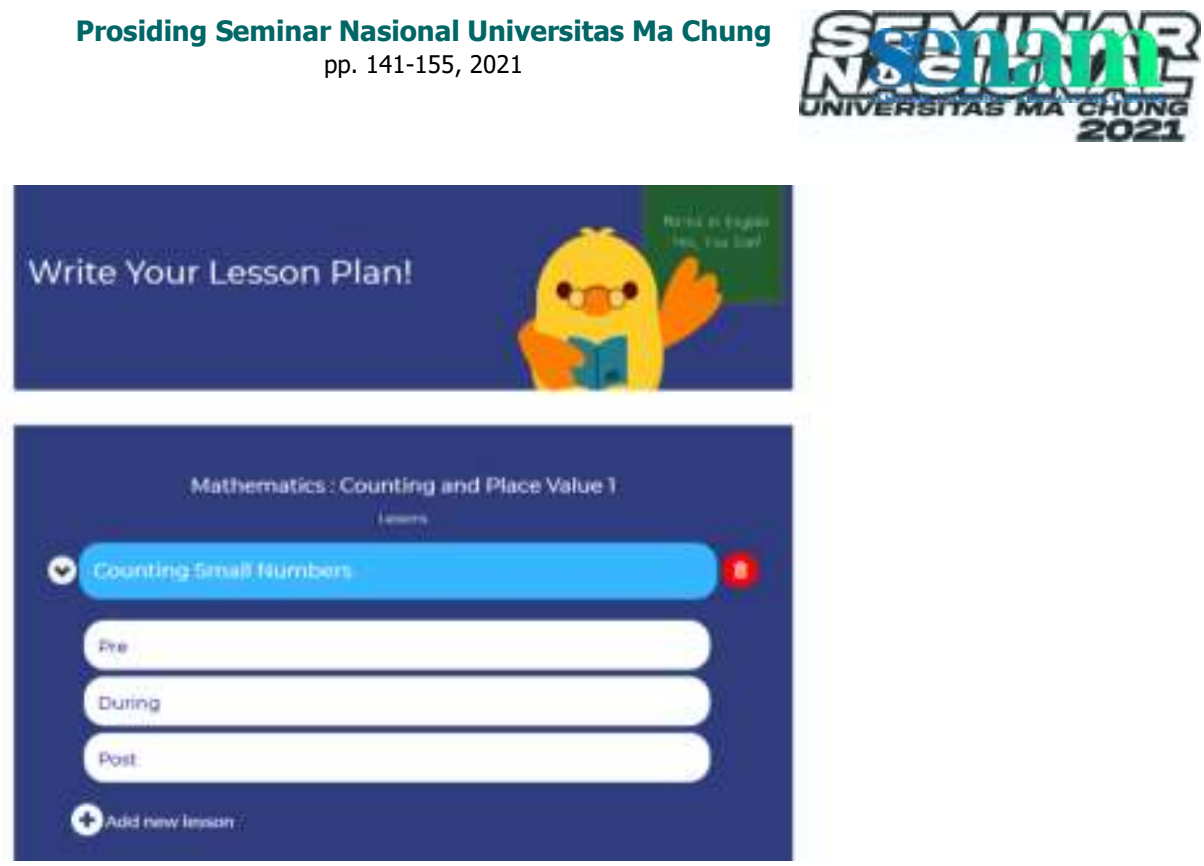

Figure 5. Add Lesson page

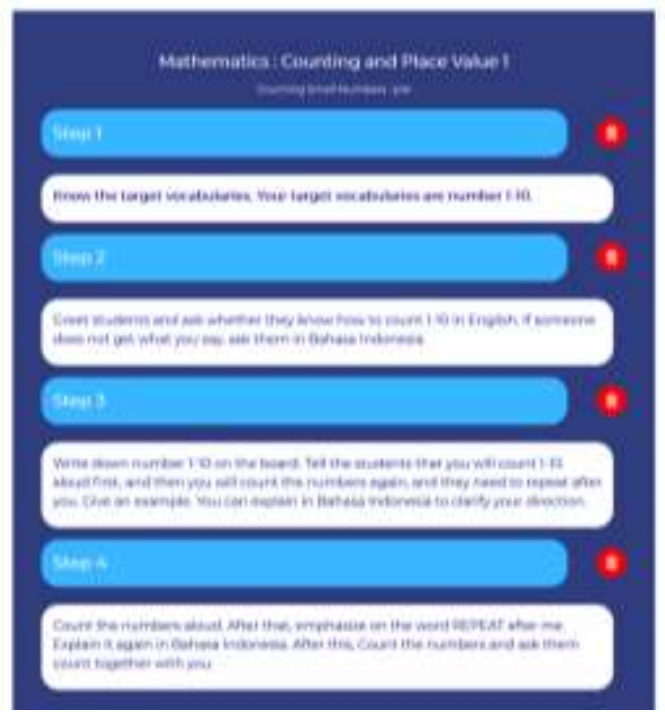

Figure 6. Step by step page

\section{Trial Report}

There were two kinds of trials, which were trials for students and trials for teachers. The trials for elementary students were held from 20 October 2020 until 28 October 2020. There were 13 elementary students and four teachers participating in the trials which were held in the CLIL course studio.

\section{Trial for Students Result}

Table 1. Ratings from Elementary Students for Klugee Learning App (KLA)

No Name Initial Rate 1-10




\begin{tabular}{cccccccc}
\hline & & $\begin{array}{c}\text { School } \\
\text { Grade }\end{array}$ & $\begin{array}{c}\text { Easiness of } \\
\text { use }\end{array}$ & $\begin{array}{c}\text { Interesting } \\
\text { level }\end{array}$ & Fun aspect & Understandable & $\begin{array}{c}\text { Prefer } \\
\text { KLA over } \\
\text { other } \\
\text { similar } \\
\text { platform }\end{array}$ \\
\hline 1 & F & 1 & 10 & 9 & 9 & 10 & YES \\
2 & J & 2 & 10 & 10 & 10 & 10 & YES \\
3 & R & 2 & 10 & 10 & 10 & 10 & YES \\
4 & A & 2 & 10 & 10 & 10 & 10 & YES \\
5 & S & 2 & 10 & 10 & 10 & 10 & YES \\
6 & A2 & 2 & 10 & 10 & 10 & 10 & YES \\
7 & S2 & 2 & 9 & 8 & 9 & 10 & YES \\
8 & R & 3 & 10 & 10 & 10 & 10 & YES \\
9 & D & 3 & 10 & 10 & 10 & 10 & YES \\
10 & A2 & 4 & 10 & 10 & 10 & 10 & YES \\
11 & K & 4 & 10 & 10 & 10 & 10 & YES \\
12 & T & 4 & 10 & 10 & 10 & 10 & YES \\
13 & A & 4 & 10 & 10 & 10 & 10 & YES \\
\hline & Mean & & 9,92 & 9,76 & 9,84 & 10 & YES \\
\hline & & & & & & & \\
\hline
\end{tabular}

In the trials for students, students finished 20 questions. Students did the first-grade level which was composed of Counting Small Numbers. After doing 20 questions in the Exercise Page, each student was asked to give feedback on the ease of use, fun aspect, interesting level, and understandable questions. The students were also asked whether they preferred to choose Klugee Learning App over other similar platforms. The feedback was given in a form of rating from 1 to 10 . The rating 1 meant very low, and 10 meant very good. The overall results showed that Klugee Learning Application was rated very good in terms of ease of use (rated 9.9 out of 10), interesting level (9.7 out of 10), fun aspect (9.8 out of 10), and understandable question (10 out of 10). All students preferred Klugee Learning Application over Khan Academy for learning mathematics in English. When asked for comments on the Klugee Learning Application, the common key words given by the participants were Less boring than the similar application, Cute, Colorful, Easier to understand.

\section{Trial for Teachers Result}

Table 2. Ratings from Mathematics teachers for Klugee Learning App (KLA) 


\begin{tabular}{|c|c|c|c|c|c|c|c|}
\hline \multirow[b]{2}{*}{ No } & \multirow[b]{2}{*}{ Name Initial } & \multicolumn{5}{|c|}{ Rate $1-10$} & \multirow[b]{2}{*}{$\begin{array}{l}\text { Prefer KLA } \\
\text { over other } \\
\text { similar } \\
\text { platform }\end{array}$} \\
\hline & & $\begin{array}{c}\text { Months of } \\
\text { teaching } \\
\text { Mathematics }\end{array}$ & $\begin{array}{c}\text { Easiness } \\
\text { of use }\end{array}$ & $\begin{array}{l}\text { The use of } \\
\text { vocabularies } \\
\text { for } \\
\text { Indonesian } \\
\text { children }\end{array}$ & $\begin{array}{c}\text { Student } \\
\text { Management }\end{array}$ & $\begin{array}{c}\text { Question } \\
\text { Management }\end{array}$ & \\
\hline 1 & A.F & 24 & 10 & 10 & 10 & 9 & YES \\
\hline 2 & E.B & 11 & 10 & 10 & 10 & 9 & YES \\
\hline 3 & M.R & 6 & 10 & 10 & 10 & 9 & YES \\
\hline 4 & D.A.P & 6 & 10 & 10 & 10 & 9 & YES \\
\hline & Mean & & 10 & 10 & 10 & 9 & YES \\
\hline
\end{tabular}

Table 3. Ratings from Mathematics teachers for Klugee Teaching Guide (KTG)

\begin{tabular}{|c|c|c|c|c|c|c|c|}
\hline \multirow[b]{2}{*}{ No } & \multirow[b]{2}{*}{ Name } & \multirow[b]{2}{*}{$\begin{array}{l}\text { Months of } \\
\text { teaching } \\
\text { Mathematics }\end{array}$} & \multicolumn{4}{|c|}{ Rate $1-10$} & \multirow{2}{*}{$\begin{array}{l}\text { Prefer } \\
\text { KTG } \\
\text { app over } \\
\text { other } \\
\text { LMS }\end{array}$} \\
\hline & & & $\begin{array}{l}\text { Easiness } \\
\text { of use }\end{array}$ & Helpfulness & $\begin{array}{c}\text { Student } \\
\text { Management }\end{array}$ & $\begin{array}{l}\text { Admin } \\
\text { Page }\end{array}$ & \\
\hline 1 & A.F & 24 & 10 & 10 & 10 & 10 & YES \\
\hline 2 & E.B & 11 & 10 & 10 & 10 & 10 & YES \\
\hline 3 & M.R & 6 & 10 & 10 & 10 & 10 & YES \\
\hline 4 & D.A.P & 6 & 10 & 10 & 10 & 10 & YES \\
\hline & Mean & & 10 & 10 & 10 & 10 & YES \\
\hline
\end{tabular}

The participants tried the two applications, which were Klugee Learning App and Klugee Teaching Guide App. During trial for Klugee Learning App, the participants accessed the Teacher's Page, Student's Page, and also the Admin Page. In the Klugee Teaching Guide application, they accessed the main page and the admin page. After trying the applications, participants were asked to give feedback in a form of rating from 1 to 10 . In the Klugee Learning Application, participants rated the ease of use, the use of vocabularies for children, student management and question management. In the Klugee Teaching Guide Application, participants rated the ease of use, helpfulness, student management, and admin page. Participants were then asked whether they would rather choose Klugee Learning App and Klugee Teaching Guide Application over other learning management systems.In the trials for Klugee Learning Application, the ratings were high. All participants rated 10 out of 10 for easiness of use, the use of vocabularies for Indonesian 
children, and student management. The question management was rated 9 out of 10 . All participants preferred Klugee Learning Application over Khan Academy for learning mathematics in English. When asked for comments on the Klugee Learning Application, the common key words given by the participants were Easier to navigate than the other app, Cute, Fresh, and Suitable for children.

\section{CONCLUSION}

As the use of technology is highly important in the present time, web-based applications can help facilitate teachers and students in the CLIL classroom practice. In this teaching media project, two applications have been built which can be used to assist teachers in the CLIL classroom. The first application is Klugee Learning Application (KLA) which works as the major teaching medium, and the second is Klugee Teaching Guide (KTG) application which works as a supplementary teaching medium. Klugee Learning Application (KLA) is built for Indonesian teachers to teach CLIL teaching, which is mathematics in English. The application comprises the main parts of the CLIL learning which are curriculum management, lesson content, exercises and quiz content, and classroom management. The Student's Page in the KLA is designed to follow the concrete operational development phase, where the students can fluently grasp the concept of counting, volume, shapes, and graphs, and questions related to their real-life activities. The second application, which is Klugee Teaching Guide (KTG) application, works to direct teachers during mathematics class sessions from pre-teaching, during teaching, and post-teaching.

There are several factors that differentiate Klugee from other similar applications. The first factor is that Klugee uses simple vocabularies that are understandable for Indonesian elementary English learners. The second factor is the lesson content video or material that includes explanation in Bahasa Indonesia to cater beginner English learners. The third factor is the supplementary Teaching Guide Application that can show step-by-step guides for teachers to teach mathematics in English to Indonesian elementary students. The fourth factor is the Student's Page interface that is suitable for young learners. These two teaching media work side by side to help reduce CLIL teachers' workloads in material preparation and student management.

Based on the trial result, teachers gave high scores in the easiness of use, student management, and the vocabularies used for Indonesian elementary students. The application 
seemed to increase students' interest in the mathematical learning which is proved by the high score in the interesting level and fun aspect.

Last but not least, this project is an interdisciplinary collaboration project involving Universitas Ma Chung's students from Informatics Engineering study program, Visual Communication Design study program, English Literature study program, and an Informatics Engineering student from Institut Teknologi Bandung. Collaboration is the key element to create a web-based teaching medium. Web-applications are like living products which need regular update and further development. Therefore, the development for both Klugee Learning Application and Klugee Teaching Guide application will not stop here. This project acts as a starting point for the teaching media to grow and develop into a mature application which can reach national audiences in the future.

\section{ACKNOWLEDGEMENTS}

Gratitude is given to the contributors of this project; advisors of this project, Professor Patrisius Istiarto Djiwandono and Lilis Lestari Wilujeng, S.S., M.Hum.; software developers Reinaldo Sebastian Gunawan, Fernandito Yoga Danny, Syafiq Faray, Octaviani Intan Riadi, Alexander Eric Wijaya, and Jehezkiel Ludwig Hadiwidjaja; illustration and assets creator Gizela Angelia, Raissa Fatimah, Fiola Anggraeni; questions developers Enrico Bianda Ekaristi, Benedick Dhanistia Banjuradja, Kristopher Keeler; and Klugee studio team members Cindy Fortunasari, Dyah Ayu Purbasari, and Maria Regina Chandra Kirana Saraswati.

\section{REFERENCES}

Aotani, N. (2017). On introducing CLIL into foreign language activities in alementary schools in Japan. http://54.199.144.1/dspace/bitstream/11334/1456/1/kyokiyo_002_06.pdf

Hauff, A. (2018). The know it all guide to color psychology in marketing + the best Hex chart. https://coschedule.com/blog/color-psychology-marketing/\#psychology

Karadeniz, M. (2015). The use of technology in the context of mathematics teaching of classroom. https://dergipark.org.tr/tr/pub/kdeniz/issue/16877/175703

Marsh, D (2002) CLIL/EMILE the European dimension. Actions, trends, and foresight potential. https://jyx.jyu.fi/bitstream/handle/123456789/47616/1/david_marshreport.pdf

Marsh, D (2013) Content and language integrated learning (CLIL).A development trajectory. https://helvia.uco.es/handle/10396/8689

National Governors Association Center for Best Practices, Council of Chief State School 
Officers (2010). Common Core State Standards Mathematics. National Governors Association Center for Best Practices, Council of Chief State School Officers, Washington D.C.

Nikula,T. (2010) Language use and language learning in CLIL classrooms.

Piaget, J. (2003). Part I: Cognitive Development in Children--Piaget Development and Learning. Journal of Research in Science Teaching, Vol.40, 8-18. https://eric.ed.gov/?id=EJ773455

Prochazkova, L.T. (2013) Mathematics for Language, Language for Mathematics. European Journal of Science and Mathematics Education Vol. 1(1), 23-28 https://files.eric.ed.gov/fulltext/EJ1108199.pdf

Surmont, J. (2016). The effects of CLIL on mathematical content learning: A longitudinal study. Uniwersytet Adama Mickiewicza, Kalisz. Studies in Second Language Learning and Teaching Vol. 6(2), 319-337. https://www.ceeol.com/search/articledetail?id=411489

Wakui, F. (2019). Effectiveness of the CLIL Methods for Japanese Learners of English. The LLL SIG Newsletter, Vol. 15

(2).http://hosted.jalt.org/lifelong/journal/2019b/2019b-Wakui.pdf

(C) 2021 by authors. Content on this article is licensed under a Creative Commons Attribution 4.0 International license. (http://creativecommons.org/licenses/by/4.0/). 